\title{
SISTEM PENILAIAN KINERJA KARYAWAN PT. CAHAYA IQRA MANDIRI MENGGUNAKAN METODE ANALYTICAL HIERARCHY PROCESS
}

\author{
Sarwindah Sarwindah ${ }^{1}$, Marini Marini ${ }^{2}$ \\ 1indah_syifa@atmaluhur.ac.id, ${ }^{2}$ arinimarini44@atmaluhur.ac.id \\ 1,2Sistem Informasi, STMIK Atma Luhur
}

\begin{abstract}
Abstrak
Dalam kehidupan sehari-hari manusia sering menemui masalah dalam pengambilan keputusandimana masalah yang muncul dapat berskala besar atau kecil yang sangat berpengaruh dalam hasil keputusan. Sekarang ini manusia mulai mengembangkan sistem yang dapat membantu menentukan alternatif terbaik dalam suatu permasalahan, yaitu sistem pendukung keputusan (SPK) di dalam sistem pendukung keputusan terdapat alternatif, kriteria dan bobot yang digunakan untuk menentukan suatu solusi terbaik. Kualitas sumber daya manusia merupakan salah satu faktor penunjang untuk meningkatkan produktivitas kinerja suatu instansi. Maka dari itu sumber daya manusia yang berkompetisi tinggi dapat mendukung tingkat kinerja, dengan penilaian kinerja maka akan diketahui prestasi yang dicapai setiap karyawan, hal ini dapat digunakan oleh instansi sebagai pertimbangan dalam menentukan karyawan terbaik. Tujuan penelitian ini adalah untuk membuat sistem pendukung keputusan yang baik yang dapat membantu manager dalam melakukan penilaian kinerja seorang karyawan di suatu instansi. Dilihat dari permasalahan penilaian kinerja seorang karyawan pada PT.cahaya iqra mandiri merupakan objek penelitian yang menghasilkan jawaban yang di inginkan yaitu Bagian Admin yang menjadi prioritas dan dapat di implementasikan untuk menetukan Administrasi yang rapi dan punya tanggung jawab yang penting di PT.cahaya iqra mandiri.
\end{abstract}

Kata kunci: Sistem, Penilaian Kinerja dan AHP

\section{Abstract}

In everyday life, humans often encounter problems in decision making, where problems that arise can be large or small, which are very influential in the results of decisions. Now humans are developing systems that can help determine the best alternative in a problem, namely the decision support system (DSS) in the decision support system there are alternatives, criteria and weights used to determine the best solution. The quality of human resources is one of the supporting factors to improve the performance productivity of an agency. So, from that competent human resources can support the level of performance, with performance appraisal, it will be known the achievements of each employee, this can be used by agencies as a consideration in determining the best employees. The purpose of this study is to create a good decision support system that can assist managers in evaluating the performance of an employee in an agency. Judging from the problem of the performance appraisal of an employee at PT. Cahaya iqra Mandiri is the object of research that produces the desired answer, the Admin section is a priority and can be implemented to determine neat administration and have important responsibilities in PT. cahaya iqra Mandiri.

Keywords: System, Performance Assessment, AHP.

\section{Pendahuluan}

Kehidupan sehari-hari manusia sering menemui masalah dalam pengambilan keputusan Masalah yang muncul dapat berskala besar atau kecil yang sangat berpengaruh dalam hasil keputusan. Sekarang ini manusia mulai mengembangkan sistem yang dapat membantu menentukan alternatif terbaik dalam suatu permasalahan, yaitu sistem pendukung keputusan (SPK) di dalam sistem pendukung keputusan terdapat alternatif, kriteria dan bobot yang digunakan untuk menentukan suatu solusi terbaik. Kualitas sumber daya manusia merupakan salah satu faktor penunjang untuk meningkatkan produktivitas kinerja suatu instansi. Maka dari itu sumber daya manusia yang berkompetisi tinggi dapat mendukung tingkat kinerja, dengan penilaian kinerja maka akan diketahui prestasi yang dicapai setiap karyawan, hal ini dapat digunakan oleh instansi sebagai pertimbangan dalam menentukan karyawan terbaik. Penilaian kinerja karyawan memiliki indikator dalam proses penilaiannya. Adapun indikator penilaian tersebut adalah sebagai berikut: penilaian umum, penilaian dilakukan dengan menggunakan alat ukur berupa kuesioner, penilai dapat bersumber dari atasan langsung. Tingkat kehadiran, skor kehadiran dihitung berdasarkan persentase jumlah kehadiran yang 
ILKOM Jurnal Ilmiah Volume 11 Nomor 2 Agustus 2019

Terakreditasi peringkat 3 SK. No. 28/E/KPT/2019

diambil dari hasil rekapitulasi finger print, kemudian dibandingkan antara total waktu kerja yang dicapai pegawai dan jumlah waktu kerja ideal tiap pegawai dikalikan $100 \%$. tingkat pendidikan, jumlah skor yang diperoleh disesuaikan dengan tingkat pendidika minimal yang dimiliki oleh pagawai pada masing-masing bidang pekerjaan. pendidikan yang dimaksud adalah pendidikan terakhir yang dimiliki oleh karyawan. unsur penunjang meliputi, aktifitas yang dilakukan di luar tanggung jawab pekerjaan, yang mendukung pegembangan karir dan pengambangan bakat pegawai, meliputi keterlibatan di masyarakat atau organisasi baik di dalam maupun di luar UPM. pengembangan diri meliputi, berbagai pelatihan yang diikuti pegawai dalam rangka meningkatkan ketrampilan yang berhubungan dengan bidang pekerjaan.

\section{Metode}

Metodologi perancangan sistem dalam penelitian ini adalah menggunakan motode Analytical Hierarchy Process (AHP) dilakukan dengan beberapa tahap yaitu mendefinisikan masalah, Menetapkan Prioritas Elemen, sintesis, menghitung konsistensi.

2.1 Mendefinisikan masalah

Menentukan solusi yang diinginkan lalu meyusun hirarki dari permasalahan yang dihadapi. Penyusunan hirarki yaitu menetapkan tujuan yang merupakan sasaran sistem secara keseluruhan pada level teratas.

2.2Menetapkan prioritas elemen

Langkah pertama dalam menentukan prioritas elemen yaitu dengan membuat perbandingan berpasangan, yaitu membandingkan elemen secara berpasangan sesuai kriteria yang diberikan.

\subsection{Sitesis}

Untuk memperoleh prioritas secara keseluruhan maka pertimbangan-pertimbangan terhadap perbandingan berpasangan perlu disintesis. Dalam hal ini hal yang dilakukan adalah:

a. Menjumlahkan nilai-nilai dari setiap kolom pada matriks

b. Membagi setiap nilai dari kolom dengan total kolom yang bersangkutan untuk memperoleh normalisasi matriks.

c. Menjumlahkan nilai-nilai dari setiap baris dan membaginya dengan jumlah elemen untuk mendapatkan nilai rata-rata.

\subsection{Mengukur konsistensi}

Dalam pembuatan keputusan, tingkat konsistensi penting untuk diperhatikan karena kita tidak menginginkan keputusan bersadarkan pertimbangan dengan konsistensi yang rendah. Hal-hal yang dilakukan dalam hal ini adalah:

a. Mengalikan setiap kolom pada nilai kolom pertama dengan prioritas relatif elemen pertama, nilai pada alemen kedua dengan prioritas relatif elemen kedua, dan seterusnya.

b. Jumlahkn setiap baris

c. Hasil dari penjumlahan baris dibagi elemen prioritas yang bersangkutan

d. Jumlahkan hasil bagi diatas dengan banyaknya elemen yang ada hasilnya disebut I maks.

\subsection{Penggabungan Pendapat Responden}

a. Pada dasarnya AHP dapat digunakan untuk mengolah data dari satu responden ahli. Namun demikian dalam aplikasinya penilaian kriteria dan alternatif dilakukan oleh beberapa ahli multidisipliner. Konsekuensinya pendapat beberapa ahli tersebut perlu dicek konsistensinya satu persatu. Pendapat yang konsisten kemudian digabungkan dengan menggunakan rata-rata geometrik.

$$
\overline{X_{G}}=\prod_{i=1}^{\overline{\pi^{n}}} \cdot X_{i}
$$

di mana:

$$
\bar{X}_{G} \quad=\text { rata-rata geometrik }
$$

$\mathrm{n}=$ jumlah responden

$X_{i}=$ penilaian oleh responden ke- $\mathrm{i}$

Hasil penilaian gabungan ini yang kemudian diolah dengan prosedur AHP.

\subsection{Metode Pegumpulan Data}

Metode pengumpulan data merupakan suatu metode yang digunakan untuk mengumpulkan data dalam proses penelitian ini. Berikut ini adalah metode pengumpulan data yang dipakai dalam proses pengumpulan data 


\section{ILKOM Jurnal IImiah Volume 11 Nomor 2 Agustus 2019}

Terakreditasi peringkat 3 SK. No. 28/E/KPT/2019

\section{a. Studi pustaka}

Yaitu mempelajari buku-buku dan referensi-referensiyang dibutuhkan yang berhubungan dengan masalah yang dibahas dalam penyusunan laporan ini.

b. Wawancara

Dilakukan dengan bertanya langsung kepada pihak pihak yang terkait yang dapat memberikan informasi tentang objek penelitian.

c. Observasi

Yaitu datang langsung ke perusahaan atau instansi yang sedang melakukan penilaian kinerja karyawan.

d. Quesioner

Yaitu suatu teknik pengumpulan informasi yang memungkinkan analis mempelajari sikap-sikap, keyakinan, perilaku, dan karakteristik beberapa orang utama di dalam organisasi.

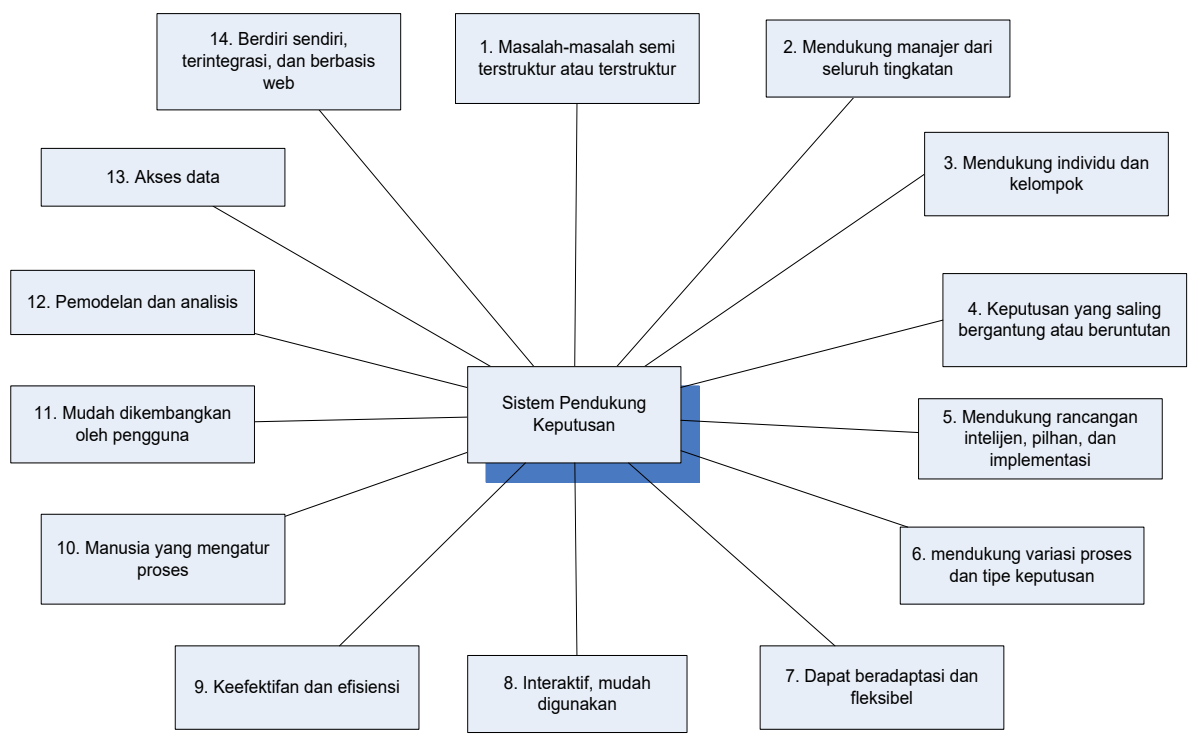

Gambar 1. Karakteristik inti SPK

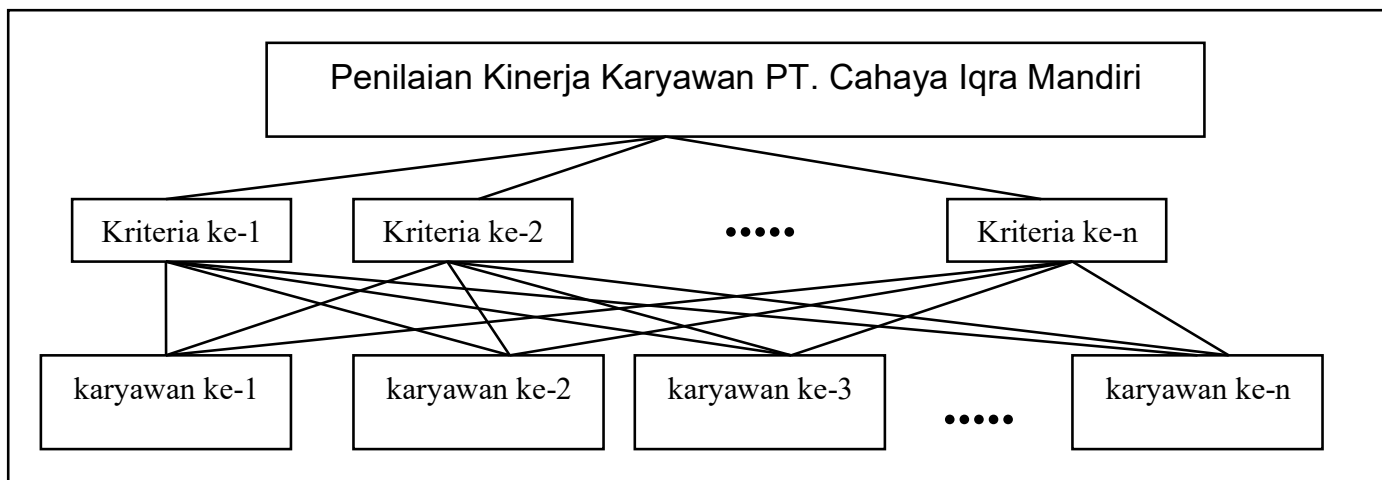

Gambar 2. Struktur Hirarki AHP pada sistem penilaian kinerja karyawan pt.cahaya iqra mandiri

\section{Hasil dan Pembahasan}

Analisa masalah dalam penilaian kinerja karyawan harus dengan melakukan pengamatan terhadap karyawan yang ada di PT. Cahaya iqra mandiri. Kemudian hasil pengamatan digunakan untuk menentukan kriteria dan sub kriteria. Selanjutnya menentukan alternative berdasarkan kebutuhan kriteria dan sub kriteria yang telah ditentukan. Data yang telah diperoleh kemudian dibuat ke dalam kuesioner untuk diisi oleh peneliti untuk menilai karyawan yang ada di PT. Cahaya iqra mandiri. Setelah semua kuesioner telah diisi, kuesioner langsung dihitung menggunakan Expert Choice 2000. 
ILKOM Jurnal Ilmiah Volume 11 Nomor 2 Agustus 2019 Terakreditasi peringkat 3 SK. No. 28/E/KPT/2019

3.1. Hasil Pengolahan Data Responden dan Hasil Implementasi Dengan Software Expert Choice Landasan kriteria dalam penilaian kinerja karyawan pada PT. Cahaya Iqra Mandiri, Untuk mendapatkan hasil keputusan yang konsisten (inconsistency $=0,00$ ), data hasil olah manual dengan nilai $<1$ perlu diadaptasi untuk pairwise comparison, menggunakan $a_{i j}=\frac{\omega_{j}}{\omega_{i}}=\frac{1}{\omega_{i} / \omega_{j}}=\frac{1}{a_{i j}}$ rumus:

a. Dalam penilaian kinerja karyawan terdapat 5 kriteria yaitu Kepribadian, Keahlian, Prestasi, Disiplin, Keterampilan didapati dari hasil perbandingan berpasangan gabungan dari responden hasilnya sebagai berikut :

Priorities with respect to: Goal: PENILAIAN KINERIA KARY...

Combined
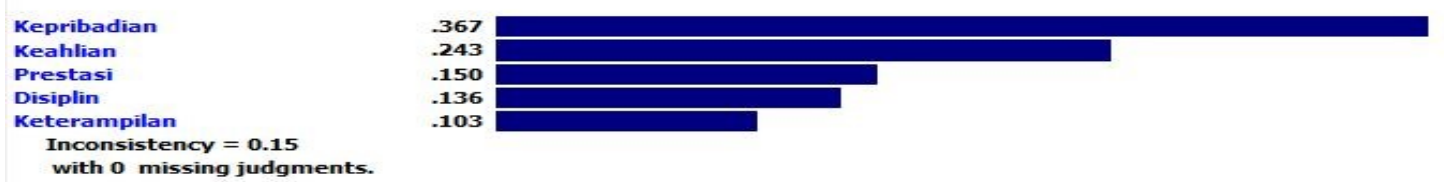

Gambar 3. Prioritas Kriteria dalam Penilaian Kinerja Karyawan beserta nilai bobotnya.

Dari hasil analisa mendapat gabungan responden menunjukkan bahwa kriteria Kepribadian (nilai bobot 0,367 atau sebanding dengan $36,7 \%$ dari total kriteria) merupakan responden paling penting dalam penilaian kinerja karyawan. Kriteria Keahlian menjadi pertimbangan kedua (nilai bobot 0,243 atau sebanding dengan $24,3 \%$ dari total kriteria) merupakan responden kedua dari penilaian kinerja karyawan. Kriteria Prestasi (nilai bobot 150 atau sebanding dengan 15,0\% dari total kriteria) merupakan pertimbangan ketiga dari penilaian kinerja karyawan. Kriteria Disiplin (nilai bobot 136 atau sebanding dengan $13,6 \%$ dari total kriteria). Sedangkan Keterampilan (nilai bobot 103 atau sebnading dengan $10,3 \%$ dari total kriteria) merupakan kriteria terakhir dalam penilaian kinerja karyawan.

b. Landasan Sub Kriteria Penilaian Kinerja Karyawan Di PT.cahaya iqra mandiri berdasarkan Kriteria Kepribadian ada 3 Sub Kriteria yaitu Penampilan, Kesopanan, Kejujuran didapati hasilnya sebagai berikut:

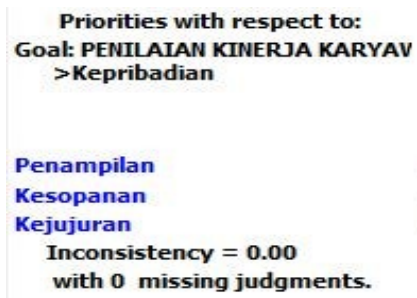

Gambar 4. Sub Kriteria dari Kriteria "Kepribadian" dalam Penilaian Kinerja Karyawan beserta nilai bobotnya.

Dari hasil analisa mendapat gabungan responden menunjukkan bahwa Sub Kriteria Penampilan (nilai bobot 0,551 atau sebanding dengan $55,1 \%$ dari total sub kriteria) merupakan Sub kriteria yang lebih penting dalam penilaian kinerja karyawan. Sub kriteria Kesopanan (nilai bobot 310 atau sebanding dengan $31,0 \%$ dari total sub kriteria) merupakan pertimbangan kedua dalam penilaian kinerja karyawan, sedangkan yang terakhir Kriteria Kejujuran (nilai bobot 140 atau sebanding dengan $14,0 \%$ dari total sub kriteria).

c. Landasan Sub Kriteria Penilaian Kinerja Karyawan Di PT.cahaya iqra mandiri berdasarkan perbandingan Kriteria Keahlian atas 2 Sub Kriteria yaitu Tata bahasa, Pelayanan didapati hasilnya sebagai berikut:
Priorities with respect to:
Combined
Goal: PENILAIAN KINERJA KARYAV

$>$ Keahlian

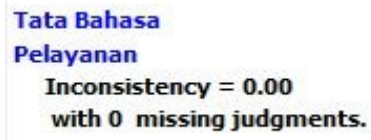

Gambar 5. Sub Kriteria dari Kriteria "Keahlian" dalam penilaian kinerja karyawan beserta nilai bobotnya. 
ILKOM Jurnal Ilmiah Volume 11 Nomor 2 Agustus 2019

Terakreditasi peringkat 3 SK. No. 28/E/KPT/2019

Dari hasil analisa gabungan responden menunjukkan bahwa Sub kriteria Tata bahasa merupakan yang lebih penting (nilai bobot 596 atau sebanding dengan $59,6 \%$ dari total sub kriteria), dan Sub kriteria Pelayanan merupakan hasil kedua dari gabungan reponden (nilai bobot 404 atau sebanding dengan $40,4 \%$ dari total sub kriteria).

d. Landasan Sub Kriteria Penilaian Kinerja Karyawan Di PT.cahaya iqra mandiri berdasarkan Kriteria Prestasi ada 3 Sub Kriteria yaitu Pemasaran, Kreatifitas, Penugasan didapati hasilnya sebagai berikut:
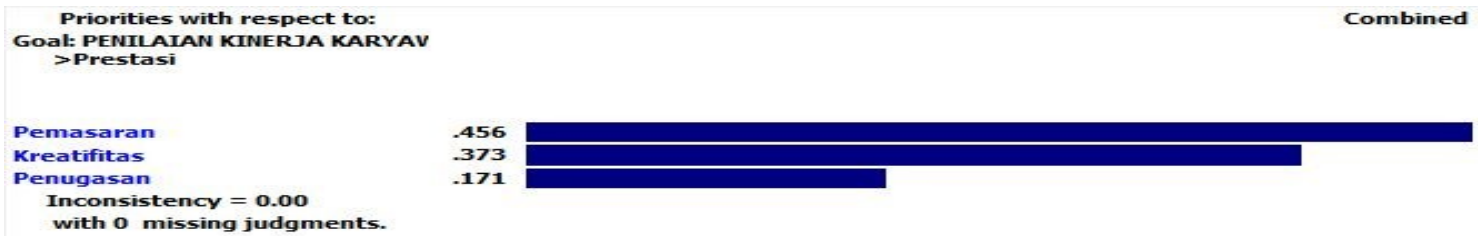

Gambar 6. Sub kriteria dari kriteria "Prestasi" dalam penilaian kinerja karyawan beserta nilai bobotnya.

Dari hasil analisa gabungan responden menunjukkan bahwa Sub kriteria Pemasaran dari kriteria Prestasi merupakan bagian yang lebih penting dari Sub kriteria lainnya (nilai bobot 456 atau sebanding dengan $45,6 \%$ dari total sub kriteria), dan yang kedua Sub kriteria Kreatifitas (nilai bobot 373 atau sebanding dengan $37,3 \%$ dari total sub kriteria) ,yang terakhir sub kriteria Penugasan (nilai bobot 171 atau sebanding dengan $17,1 \%$ dari total sub kriteria).

e. Landasan Sub Kriteria Penilaian Kinerja Karyawan Di PT.cahaya iqra mandiri berdasarkan Kriteria Disiplin ada 2 Sub Kriteria yaitu Kehadiran, Ketegasan didapati hasilnya sebagai berikut:

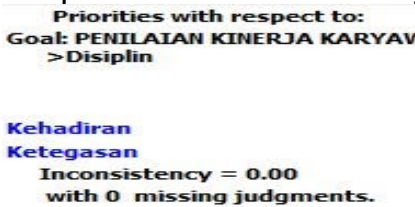

Gambar 7. Sub kriteria dari kriteria "Disiplin" dalam penilaian kinerja karyawan beserta nilai bobotnya.

Dari hasil analisa gabungan reponden menunjukkan Sub kriteria Kehadiran(nilai bobot 632 atau sebanding dengan $63,2 \%$ dari total sub kriteria) merupakan hasil yang lebih penting dari sub kriteria Ketegasan (nilai bobot 368 atau sebanding dengan 36,8\% dari total sub kriteria).

f. Dari hasil analisa gabuLandasan Sub Kriteria Penilaian Kinerja Karyawan Di PT.cahaya iqra mandiri berdasarkan Kriteria Keterampilan ada 2 Sub Kriteria. yaitu Pengawasan, Kepemimpinan didapati hasilnya sebagai berikut: Priorities with respect to:

Goal: PENILAIAN KINERJA KARYAV

Combined

$>$ Keterampilan

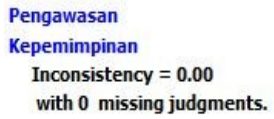

Gambar 8. Sub kriteria dari kriteria "Keterampilan " dalam penilaian kinerja karyawan beserta nilai bobotnya.

Dari hasil analisa gabungan responden menunjukkan Sub kriteria Pengawasan (nilai bobot 754 atau sebanding dengan $75,4 \%$ dari total sub kriteria) merupakan sub kriteria lebih penting, sedangkan sub kriteria kepemimpinan (nilai bobot 246 atau sebanding dengan $24,6 \%$ dari total sub kriteria) merupakan sub kriteria terakhir dalam penilaian kinerja karyawan.

g. Landasan Alternatif Penilaian Kinerja Karyawan Di PT.cahaya iqra mandiri berdasarkan Kriteria Kepribadian dan Sub kriteria Kejujuran. yaitu Bagian Admin, Staf gudang, Supir didapati hasilnya sebagai berikut: 
ILKOM Jurnal Ilmiah Volume 11 Nomor 2 Agustus 2019

Terakreditasi peringkat 3 SK. No. 28/E/KPT/2019

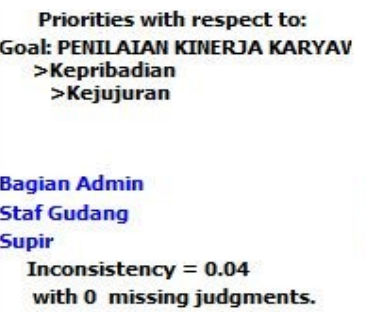

with 0 missing judgments.

Combined

Gambar 9. Alternatif dari gabungan Kriteria "Kepribadian" dan Sub kriteria "Kejujuran" dalam penilaian kinerja karyawan beserta nilai bobotnya.

Dari hasil analisa gabungan responden menunjukkan alternatif dari kriteria Kepribadian dan Sub kriteria Kejujuran "Bagian Admin" (nilai bobot 591 atau sebanding dengan 59,1\% dari total alternatif) , Staf gudang(nilai bobot 285 atau sebanding dengan 28,5\% dari total alternatif), Supir (nilai bobot 124 atau sebanding dengan $12,4 \%$ dari total alternatif).

h. Landasan Alternatif Penilaian Kinerja Karyawan Di PT.cahaya iqra mandiri berdasarkan Kriteria Keahlian dan Sub kriteria Pelayanan. yaitu Bagian Admin, Staf gudang, Supir didapati hasilnya sebagai berikut:

Priorities with respect to:

Goal: PENILAIAN KINERJA KARYAV

$>$ Keahlian

Combined

Bagian Admin

Staf Gudang

Supir

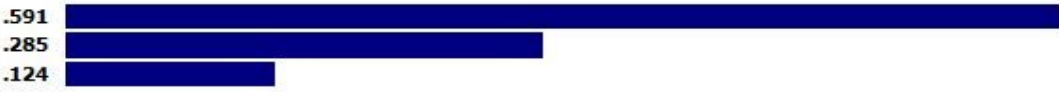

$>$ Pelayanan

Inconsistency $=\mathbf{0 . 1 6}$

with 0 missing judgments.

Gambar 10. Alternatif dari gabungan Kriteria "Keahlian" dan Sub kriteria "Pelayanan" dalam penilaian kinerja karyawan beserta nilai bobotnya.

Dari hasil analisa gabungan responden menunjukkan alternatif dari kriteria Keahlian dan Sub kriteria Pelayanan“ Bagian Admin" (nilai bobot 554 atau sebanding dengan 55,4\% dari total alternatif), Staf gudang(nilai bobot 294 atau sebanding dengan 29,4\% dari total alternatif), Supir (nilai bobot 152 atau sebanding dengan $15,2 \%$ dari total alternatif).

i. Landasan Alternatif Penilaian Kinerja Karyawan Di PT.cahaya iqra mandiri berdasarkan Kriteria Prestasi dan Sub kriteria Pemasaran. yaitu Bagian Admin, Staf gudang, Supir didapati hasilnya sebagai berikut:

Priorities with respect to:

Goal: PENILAIAN KINERJA KARYAV

$>$ Prestasi

$>$ Pemasaran

Bagian Admin

Staf Gudang

Supir

.554

.294

.152

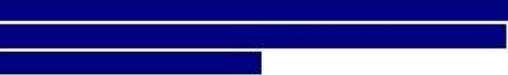

Inconsistency $=\mathbf{0 . 0 0}$

with 0 missing judgments.

Combined

Gambar 11. Alternatif dari gabungan Kriteria "Prestasi" dan Sub kriteria "Pemasaran" dalam penilaian kinerja karyawan beserta nilai bobotnya.

Dari hasil analisa gabungan responden menunjukkan alternatif dari kriteria Prestasi dan Sub kriteria Pemasaran "Bagian Admin" (nilai bobot 545 atau sebanding dengan 54,5\% dari total alternatif) Staf gudang(nilai bobot 228 atau sebanding dengan 28,8\% dari total alternatif), Supir (nilai bobot 226 atau sebanding dengan $22,6 \%$ dari total alternatif).

j. Landasan Alternatif Penilaian Kinerja Karyawan Di PT.cahaya iqra mandiri berdasarkan Kriteria Disiplin dan Sub kriteria Kehadiran, yaitu Bagian Admin, Staf gudang, Supir didapati hasilnya sebagai berikut:

Priorities with respect to:

Goal: PENILAIAN KINERJA KARYAV

$>$ Disiplin

$>$ Kehadiran

Bagian Admin

Staf Gudang

Supir

545

228

Inconsistency $=0.02$

with 0 missing judgments.

Gambar 12. Alternatif dari gabungan Kriteria "Disiplin" dan Sub kriteria "Kehadiran" dalam penilaian kinerja karyawan beserta nilai bobotnya. 
Dari hasil analisa gabungan responden menunjukkan alternatif dari kriteria Disiplin dan Sub kriteria Kehadiran "Bagian Admin" (nilai bobot 570 atau sebanding dengan 57,0\% dari total alternatif), Staf gudang(nilai bobot263 atau sebanding dengan 26,3\% dari total alternatif), Supir (nilai bobot 167 atau sebanding dengan $16,7 \%$ dari total alternatif).

k. Landasan Alternatif Penilaian Kinerja Karyawan Di PT.cahaya iqra mandiri berdasarkan Kriteria Keterampilan dan Sub kriteria Kepemimpinan, yaitu Bagian Admin, Staf gudang, Supir didapati hasilnya sebagai berikut:
Priorities with respect to:
Goa: PENILAIAN KINERJA KARYAV
$>$ Keterampilan
Combined
Bagian Admin
Staf Gudang
Inconsistency $=0.04$
with 0 missing judgments.

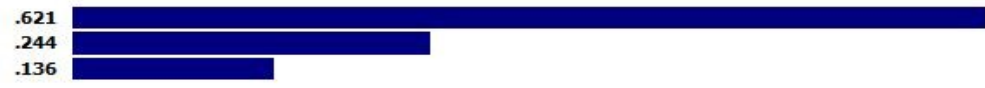

Supir

Gambar 13. Alternatif dari gabungan Kriteria "Keterampilan" dan Sub kriteria "Kepemimpinan" dalam penilaian kinerja karyawan beserta nilai bobotnya.

Dari hasil analisa gabungan responden menunjukkan alternatif dari kriteria Keterampilan dan Sub kriteria Kepemimpinan "Bagian Admin" (nilai bobot 621 atau sebanding dengan 62,1\% dari total alternatif), Staf gudang(nilai bobot 244 atau sebanding dengan 24,4\% dari total alternatif), Supir (nilai bobot 136 atau sebanding dengan 13,6\% dari total alternatif).

I. Landasan Global Prioritas Alternatif Penilaian Kinerja Karyawan Di PT.cahaya iqra mandiri didapati hasilnya sebagai berikut:

\section{Synthesis with respect to:}

Goal: PENLLAIAN KINERJA KARYAWAN DI PT. CAHAYA IQRA MITRA MANDIRI

Overal Inconsistency $=0.03$

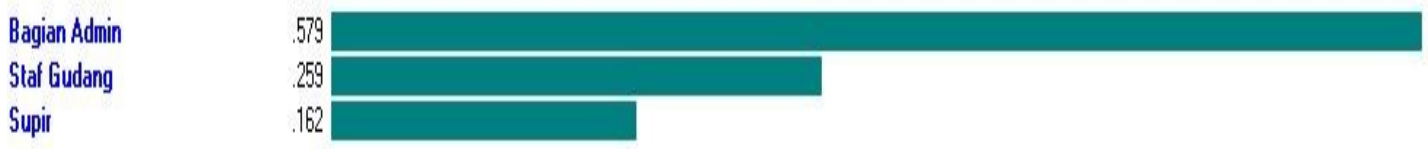

Gambar 14. Synthesis with Respect To beserta nilai bobotnya

Berdasarkan hasil pengolahan data responden diperoleh bahwa prioritas utama atau tertinggi alternatif adalah Bagian Admin dengan nilai bobot 579 atau sebanding dengan 57,9\% dari total alternatif, peringkat alternatif berikutnya adalah Staf Gudang dengan nilai bobot 259 atau sebanding dengan $25,9 \%$ dari total alternatif, dan peringkat alternatif yang terakhir adalah Supir dengan nilai bobot 162 atau sebanding dengan 16,2\% dari total alternatif yang diterapkan.

\section{Kesimpulan dan Saran}

Berdasarkan kriteria dan sub kriteria maka kinerja karyawan pada PT. Cahaya iqra mandiri yang dapat di implementasikan untuk kebutuhan prusahaan berdasarkan hasil analisa pendapat gabungan responden menunjukan bahwa prioritas utama atau tertinggi alternatifnya adalah Bagian Admin dengan nilai bobot 579 atau sebanding dengan $57,9 \%$ dari total alternatif, peringkat alternatif berikutnya adalah Staf Gudang dengan nilai bobot 259 atau sebanding dengan 25,9\% dari total alternatif, dan peringkat alternatif yang terakhir adalah Supir dengan nilai bobot 162 atau sebanding dengan $16,2 \%$ dari total alternatif yang diterapkan. Hasil yang didapat dari penelitian ini yaitu Bagian Admin yang menjadi prioritas dan dapat di implementasikan untuk menetukan Administrasi yang rapi dan punya tanggung jawab yang penting di PT. Cahaya Iqra Mandiri, sehingga tujuan dengan memanfaatkan sarana prasarana tertentu secara berdaya guna dan berhasil guna dengan acuan yang baku yaitu Kinerja karyawan. Semoga apa yang telah dirintis dalam penelitian ini dapat bermanfaat dan dapat dijadikan landasan dalam menentukan keputusan strategis dalam menentukan Kinerja karyawan di PT. Cahaya iqra mandiri.

\section{Ucapan Terima Kasih}

Terima kasih disampaikan kepada Perguruan tinggi STMIK Atma Luhur yang mendanai penelitian ini berdasarkan SK No. 002/KET/STMIK-AL/VIII/2013. 
ILKOM Jurnal Ilmiah Volume 11 Nomor 2 Agustus 2019

Terakreditasi peringkat 3 SK. No. 28/E/KPT/2019

\section{Daftar Pustaka}

[1] Turban, E., Decision Support System and Intelligent System, Prentice Hall, New Jersey, 2005

[2] Amardyah Amborowati (2004). Sistem Penunjang Keputusan Pemilihan Perumahan dengan Metode AHP menggunakan Expert Choice.

[3] Fiati, Rina ,Pemanfaatan AHP sebagai Model Sistem penunjang Keputusan Penentuan desa Posdaya,2011.

[4] Saaty, T.L., 2001, Decision Making For Leader, Forth edition, University of Pittsburgh, RWS Publications.

[5] Sarwindah, 2013. Kajian Pemilihan Software Desain Grafis Untuk Pembelajaran Dengan Metode AHP Pada SMK Muhamadiyah 9. SEMNASTEKNOMEDIA. 2013

[6] Erikson S. Sinaga, Strategi Process Migrasi Proprietary Software Ke Open Source Software Di Perusahaan Dengan Pendekatan Analytical Hierarchy Process (AHP), Studi Kasus : SGU, Tangerang, 2008.

[7] Dyah, Wulandari, , Strategi IT Disaster Recovery Plan Pada Core Banking System dengan Pendekatan Analytical Hierarchy Process, Studi Kasus : PT. Bank Mega Tbk, 2008.

[8] Sotir, Sotirov and Andrey, Nenov (2000). Tutorials Expert Choice,Vol. 4 No. 1, Maret 2006, ISSN : 1693 - 5373, Computer Science Journal.

[9] Marimin,2004 Teknik dan Aplikasi Pengambilan Keputusan Kriteria Majemuk, Penerbit PT Grassindo, Jakarta. 